is called a wind-slab avalanche, which may be very destructive.

It is characteristic of wind slabs that they do not bind themselves to the hillside, but have a hollow space underneath, which renders them all the more unstable.

Photomicrographs of the snow composing one of these wind-packed drifts or slabs showed considerable uniformity in grain size. This indicated a method of approach towards the proof of what had hitherto only been suspected, namely, that the snow had been drifted, since drifting sorts out the grains into uniform sized groups.

A study was made of a whole series of photomicrographs both of natural wind slabs and of wind slabs made under controlled conditions in an out-of-door laboratory. Ultimately it became possible to make this hitherto unexplained phenomenon, which had sent so many brave and wondering mountaineers to their deaths, yield up several of its secrets. Among other things it became possible to tell the mountaineer where on the hillside he can expect the worst wind-slab avalanches, and under what atmospheric conditions they are to be expected.

To put these findings in a nutshell : they are found on slopes to the leeward of the last snowbearing wind, when the general condition of the air is damp.

This conclusion has already borne fruit. Ever since the fatal avalanche on Mount Everest in 1922, when seven porters met their deaths, leaders of the expeditions have been puzzled by unaccountable avalanches bursting from the North Col with apparently no prime cause. They have now come to realize that these fall under just those conditions which I have pointed out, namely, a wet wind depositing the snow in drifts on lee slopes, and they have been able to link them up with the advent of the monsoon. As soon as the damp monsoon wind blows over the North Col the glacier on its lee side becomes a death-trap. An alternative route has now been reconnoitred and will, no doubt, be used in future, as soon as the conditions begin to favour wind slab development.

\title{
Origin of the Papuan Insect Fauna
}

\section{By L. Evelyn Cheesman}

$\mathrm{T}^{\mathrm{H}}$ HE island of New Guinea is a centre of distribution for species belonging to the Papuan fauna, which is very distinct and very rich in variety of forms. Yet the bulk of this huge island is part of the Himalayan geanticline, and therefore geologically recent. Since the fauna cannot have evolved upon land recently raised from the sea, there must have been older land from which the new land was populated.

Palæogeologists such as Ortmann, Lapparent, Arldt and others have postulated a land-mass which during the Middle Cretaceous extended from the Asiatic continent south to New Caledonia and eastward to Sumatra and Java. Some time during the Upper Cretaceous, according to the same authorities, New Guinea became separated from Borneo, Celebes and the Philippines, and also from New Caledonia. Later, the entire island is supposed to have been submerged until the Miocene-Pliocene folding movement raised the central ranges and land to the south.

Biological evidence with regard to the distribution of insect species supports these theories of former land-masses up to a certain point. For the Papuan insect fauna appears to be of oriental origin, showing decided affinities with the fauna of the Philippines, New Caledonia and the Moluccas ; but is distant from that of Malaysia, with the exception of a few widely dispersed species which may represent a much older fauna.

The Papuan insect fauna has also spread in a south-easterly direction as far as the Society Islands in the mid-Pacific. I think that later we shall find the Papuan element in the Pacific even stronger than it appears, when we are more familiar with true Papuan forms and are in a position to check old records. For I have discovered in many cases that species recorded as IndoMalayan, Austro-Malayan and Australasian are in reality Papuan ; even so-called Australian species are very often those recorded from tropical Queensland and therefore are also Papuan.

The origin of the peculiar endemic fauna and flora of New Guinea, however, is not explained by the work of geologists. Old mountains of continental rock do exist in New Guinea, in the central ranges and to the north ; but these have not been investigated, and may have been submerged before the Tertiary. On the north coast, however, where I recently made a collecting expedition on behalf of the British Museum (Natural History), the Cyclops Mountains and 
Mt. Bougainville in Dutch Territory (Fig. 1), and the Torricelli Range in the Mandated Territory, are of pre-Cambrian schists and gneisses, and these mountains at least show no sign of submergence. They all belong to the same geological period and have a similar geological formation.

Before leaving England for Dutch New Guinea, I tried to obtain information of the topography of this region but without success. In Netherlands Indies the Dutch authorities showed me Government geological maps (not available in England), from which it is evident that no marine deposits formed of elevated coral limestone-the old coast of the former island-and the bed of the lake has been raised 200 feet. The northern side of the range is high and steep, with cliffs sheer to the sea, and has no inlets or anchorage except the two bays east and west. It appears that the island tilted downwards on that side, but was raised on the south together with its fringing coral reefs. Mt. Bougainville farther east is also surrounded by old coral inland.

With regard to the Torricelli Range in the Mandated Territory, an oil company has been

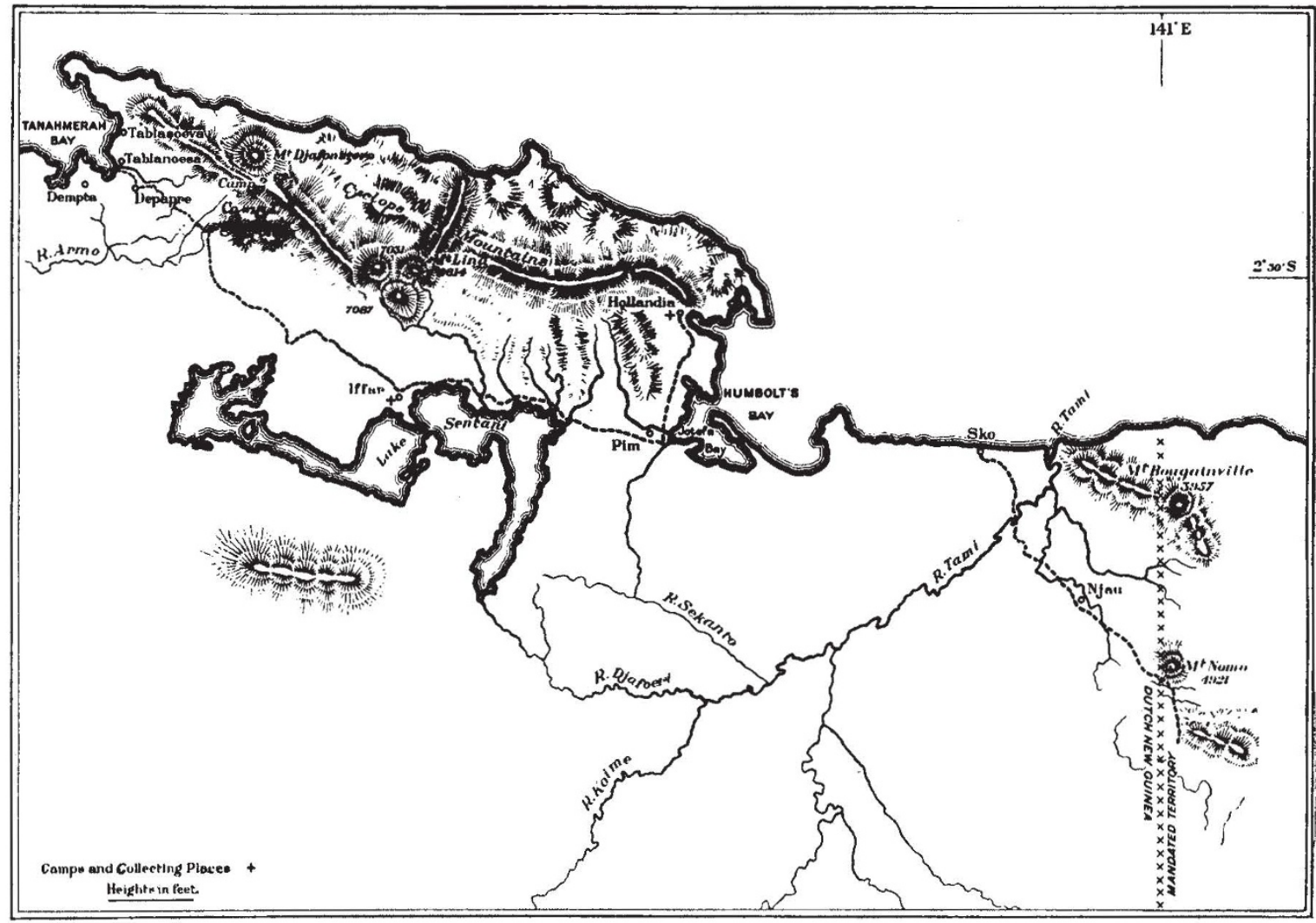

Fig. 1.

Map of the Brimsh Museum (Natural History) Expedition to the north of New Guinea

have been recorded from the Cyclops Mountains or Mt. Bougainville. What is also very interesting is that they were evidently islands, the old shores of which can be traced inland. For inland south of the Cyclops Mountains-which are a coastal range thirty miles long-is a Tertiary limestone zone. In this area I discovered an old coral cliff more than 120 feet high. Rock specimens from this cliff which I brought back with me contain Tertiary Foraminifera; and a fossil reef-shell, Strombus sp. from the bank of a stream in that neighbourhood, is also Tertiary.

At the foot of the mountains on the south lies Lake Sentani, the southern shores of which are working for eight years in that district, and the mountains with the surrounding area have been thoroughly surveyed. The company does not wish to publish maps at this stage of its work, but I learnt from its members that they had come to the same conclusion regarding the Torricelli Mountains, namely, that this range was formerly an island, and there is no evidence of submergence.

This is extremely significant in the early history of the Papuan fauna. We see that there exist in New Guinea to-day at least three mountain groups -and doubtless there are others-which were formerly islands, and have remained above the sea throughout a very long period. It is interesting. 
too to note that they all have a similar trend, and that they correspond with the crystalline schists of the island of Japen and with those of a range south of the Arfak Mountains in Vogelkopf.

If we assume that New Guinea has not been entirely submerged since very remote ages, and that remnants of the Middle Cretaceous land-mass exist to-day, this is entirely consistent with geological as well as biological evidence. It is not fantastic to consider that the land which rose from the Eocene Sea would unite these old islands, and their population would spread over the new territory ; and isolation upon islands would account for the richness of the Papuan fauna and flora.

The Papuan insect fauna is approximately one third Oriental and two thirds endemic. If we consider that this fauna consists of old forms of Oriental origin together with more recent forms derived from them, that appears to be a very plausible explanation, and provides a most helpful working hypothesis in tracing the affinities and the distribution of species.

\section{Obituary Notices}

\section{Dr. S. F, Grace}

$\mathrm{S}^{\Lambda}$ AMUEL FORSTER GRACE was born on May 10, 1895, at Huyton, near Liverpool. As a boy he attended St. Francis Xavier's College, Liverpool, where he had a very brilliant career. In 1908, 1910 and 1911 respectively he took the preliminary, junior and senior stages of the Oxford Local Examinations, and was awarded first class honours in all three. In each of the first two of these examinations he was placed "first in all England". In 1912 he entered the Faculty of Science of the University of Liverpool with valuable scholarships; and studied mathematics and physics. In 1914 he passed the examination for the ordinary degree of B.Sc., being the most distinguished student of his year in mathematics. At the outbreak of the Great War, he joined the King's Liverpool Regiment and was in France almost continuously until the summer of 1918. It was on the Somme in June 1918 that he received the wound which ultimately led to his death.

In the spring of 1919, Grace returned to the University of Liverpool and entered the honours school of mathematics. He took the honours degree in 1920 and, in spite of the gap of nearly five years in his studies, his record was one of the best which that particular school has ever had. During the session 1920-21 he worked at the Sorbonne and the Collège de France, holding scholarships which included an 1851 Exhibition Research Scholarship. In 1921 he joined the teaching staff of the Department of Mathe. matics of the University of Liverpool, and steadily progressed from the lowest to the highest grade of lecturers. He was a born teacher and had a power of getting to know the individual qualities of large numbers of students.

Before going to Paris, Grace began mathematical investigations on the motion of solids in a rotating liquid, the results of which were published in the Proc. Roy. Soc. between 1922 and 1926. He then began a series of researches on tides, the results of which were published in the Geophys. Supp., M.N.R.A.S. These fall into three groups on the following subjects : (1) The analysis of observational data with the object of finding the laws of internal friction in tidal currents, and the friction at the seabottom. (2) The theoretical determination of the distribution of the tides over the Gulf of Mexico and the Bay of Biscay. (3) The dynamical explanation of actual tides in narrow seas.

All Grace's research was marked by excellent workmanship. $\mathrm{He}_{\Theta}$ had a steady-going persistence and thoroughness and a capacity for sustained hard work which carried him far.

From 1924 his war-wound gave him serious trouble, and he had several long and grave illnesses. During periods of convalescence and before he had recovered sufficiently to give his university lectures, he worked steadily at his researches. He died on April 30, immediately following an operation, and it was characteristic of him that he had taken some proofs into the nursing home, so as to be able to correct them on his recovery. He never married. J.P.

\section{Dr. John Humphreys}

BY the death of Dr. John Humphreys, which occurred at Edgbaston on May 29, scientific and antiquarian circles in Birmingham have lost one of their most distinguished members. Born so long ago as 1850 at Llanfyllin, Montgomeryshire, he came from a family which in the previous century had given to the Church a bishop of Bangor and Hereford.

Entering the dental profession by apprenticeshipthe only method possible at the time-Humphreys began to practise in Bromsgrove, but soon moved to Birmingham. In 1883 he joined the staff of the Birmingham Dental Hospital, and with the introduction of a dental curriculum at Queen's College became lecturer on dental anatomy. After the incorporation of Queen's College and Mason College in the University of Birmingham in 1900, he continued in the lectureship, which he retained until his retirement from active professional work in 1919. During the tenure of this appointment the claims of a large practice allowed little time for research, but 